\title{
8
}

\section{EXPLAINING INSTITUTIONAL PERSISTENCE AND CHANGE IN POLISH AND CZECH HIGHER EDUCATION FROM A STAKEHOLDER PERSPECTIVE}

\author{
Aleš VIk, Michael Dobbins, and Rafał Riedel
}

\section{Introduction}

This chapter examines very different recent trends in Polish and Czech higher education (HE) while contributing to a broader discussion on organized interests in post-communist democracies. Previous research has highlighted how academic mobilization was instrumental in bringing down communism and facilitating the restoration of Humboldtian-style structures of academic selfgovernance (Dobbins, 2011; Junes, 2011; Kwiek, 2014). Indeed, both systems are characterized by numerous institutions to defend the integrity and independence of the academic profession. Throughout the 1990s, academia in both countries seemed very disinclined to any state intervention into HE, while in the 2000s and 2010s, both systems consolidated institutions of participative "academic democracy" with strong "internal” stakeholdership (Dobbins, 2014).

However, Poland has recently experienced a striking shift toward recentralization and power concentration, while the Czech system has largely remained embedded in its restored model of fragmented academic self-rule. How do we explain this divergent development, in Poland in particular? We move beyond simplified explanations that HE reflects a broader societal trend toward authoritarian nationalism in numerous Central and Eastern European (CEE) countries (Greskovits, 2015). Instead, we focus on two factors: (1) the configuration and strategies of organized academic interests vis-à-vis the state and (2) the state's capacity to govern the sector. We argue that a combination of an increasingly strong state in Poland and fragmented interest organizations resulted in the centralization of HE, while a combination of a weaker state and much more consolidated stakeholders in the Czech Republic resulted in the persistence of preexisting policy arrangements. Specifically, we show that the national-conservative Polish government strategically played with the interests 
of particular stakeholders and transformed the opportunity structures of academic organizations. Despite changes in the political landscape including the dominance of several reform-minded right-wing governments, Czech $\mathrm{HE}$ has remained almost unaffected. Internal stakeholders and institutions of "academic democracy" continue to dominate, whereby pressures and conflicts have evolved inside $\mathrm{HE}$ institutions rather than between the government and institutions.

We first look at research on HE interest groups before discussing Olson's argument about diffuse and concentrated interests. Next, we provide a brief overview of Polish and Czech HE governance with a focus on stakeholder constellations, while highlighting their similar post-communist trajectory. We then explore the driving forces for their recent divergent development. Specifically, why was the Polish government able to impose a reform, which was by objective standards desirable (see below) but whose final outcome was largely rejected by the academic community? Following Olson (1965), we show that concentrated interests, in particular Polish university rectors, were able to forge tight alliances with state policy-makers, both of which were pushing for a centralization of $\mathrm{HE}$ and concentration of power (at the systemic and university levels). This arguably has undermined well-established institutions of academic stakeholdership.

In contrast, the Czech government has never been able to gain considerable power to steer the system and push through reforms. We show that three groups of internal stakeholders - rectors, academics, and students - were able to use their concentrated power, as firmly legitimized in HE legislation, to mobilize and mutually fight off attempts to reform institutional governance and even further consolidate some autonomous features of the system. Thus, while in the Czech Republic, an "internal academic alliance" has succeeded in preserving the status quo and weakened the position of the state, a "state-rector corporatist alliance" has evolved in Poland to the detriment of other actors and stakeholder democracy.

To show how these different models of "academic corporatism" have evolved, we rely on the process-tracing method (Bennett \& George, 2005), drawing from numerous interviews with HE stakeholders (rectors, deans, professors, representatives of students' associations, and managerial staff) and open questions in a survey of Polish and Czech HE interest organizations.

\section{HE interest groups: a brief overview}

HE stakeholders remain somewhat understudied from a comparative perspective. Considering the increasing number of individuals and organizations active in $\mathrm{HE}$ though, interest organizations have become an increasingly relevant factor in $\mathrm{HE}$ governance (see Tandberg, 2010 for the American context). Drawing on the classic interest group research (Schmitter \& Streeck, 1999), Klemenčič $(2012,2014)$ distinguishes corporatist and pluralist systems. In the corporatist paradigm, the state engages with a limited number of intermediary associations often having 
a representation monopoly. This may go hand-in-hand with an administrative funding arrangement for selected organized interests. Pluralist arrangements, by contrast, are characterized by a diverse array of organizations, who often compete with one another for access to state decision-makers. Membership is generally voluntary, and the state negotiates on an ad hoc basis with some groups.

Recently, Vukasovic (2018) provided a strong impetus to the study of HE stakeholders. She argues that political decisions regarding HE must increasingly be legitimized toward economic stakeholders, fee-paying students, tax-payers, and the electorate. Thus, various organized stakeholders are increasingly present on the institutional and system-level (Gornitzka \& Maassen, 2000), as well as in supranational arenas (Jungblut \& Vukasovic, 2013). Building on Klemenčič's analyses of student unions (2012, 2014), Vukasovic (2018) breaks down HE stakeholders into three key groups: organizations representing students, academic staff, and university management. Academic staff organizations are essentially trade unions with high autonomy and a strong professional ethos (2018, p. 420). HE institutions also collectively assert their interests at different levels through rectors' conferences and alliances of university groups (e.g., polytechnics, research-oriented universities, private universities, etc.). Finally, student or academic unions may also be potent actors in shaping HE policy. In some cases, their participation may be merely symbolic, whereby in others, they actually may function as veto-players or co-agenda setters.

Besides the institutional settings, factors inherent in interest groups themselves may be decisive for influence. Olson (1965) shows how the structure and focus of interest groups may impact their means for collective action. Concentrated interests (traditionally, business groups, but in our case, also university rectors or lobbyists for certain groups of universities) generally have relatively homogenous preferences and seek concentrated benefits. Diffuse interests (e.g., here, universities academics as a whole or student lobbies) may be more difficult to organize, because they often lobby for nonexclusive public goods (e.g., better working conditions for academic staff). Accordingly, size may be critical: the bigger a group, fewer the individuals taking action to achieve common interests. Olson (1965) argues that individuals may, therefore, "free-ride" on the efforts of few members of diffuse groups. Smaller, better-consolidated groups may have an organizational advantage as they are easier to organize and monitor. Organizations involved in the implementation of (state-defined) policies may also be privileged by their crucial role in the policy cycle.

Against this background, numerous questions emerge for the study of $\mathrm{HE}$ stakeholders in Poland, the Czech Republic, and beyond. First, is the state even actively involved in policy-making? And, if not, which organized interests are dominant? How do more diffuse interest groups such as the academic profession or students overcome collective action dilemmas and wield clout? Which groups are insiders or outsiders in the policy process, and how has interest intermediation evolved over time? 


\section{The evolution of Polish and Czech HE and the stakeholder landscape from the historical perspective}

\subsection{Poland}

The history of Polish HE is particularly turbulent and characterized by a dual legacy of both academic self-governance and, since the communist phase, pervasive state regulation. Numerous Polish institutions are among the oldest in Europe, e.g., the Jagiellonian University of Cracow (1364). However, the partitions of Poland essentially terminated Polish academics for more than a century. With the reestablishment of Poland in 1918, a governance model based on Humboldtian principles of academic self-rule was reintroduced, only to be eradicated by Nazi occupiers 20-25 years later.

Nevertheless, remnants of academic self-rule persisted even after Poland succumbed to Soviet control. While the academic sector remained heavily centralized and subject to political repression and bureaucratic command-and-control, Polish academics had more freedom in teaching and research than their Soviet, Czechoslovak, or Romania counterparts (van Beek, 1995). Some contacts with western academic peers were tolerated, and Marxist-Leninist ideology was somewhat less intrusive than in other CEE countries.

After 1989, public HE essentially was realigned with a Humboldtian-type model of academic self-rule (Kwiek, 2014; for private HE see Duczmal, 2006). This "return to history" logic was reflected in the 1990 HE Act that gave public universities extensive autonomy to shape their organizational structures, financial, personnel, and enrolment policies. The historical trauma of partition, occupation, and Soviet dominance was a major leitmotiv of Polish academics' struggle to preserve their institutional autonomy (van Beek, 1995). The 1990 Act devolved decision-making to individual faculties and chairs (World Bank, 2004) while concentrating power within decentralized self-governing bodies. This severely diminished the power resources of the state, university management, and other external stakeholders.

Although the state continued to fully (under)fund public universities, internal stakeholder structures were essentially akin to an "academic oligarchy" (Clark, 1983). Academic senates were modeled after national parliaments, whereby leading academics (with the title of habilitated doctor) accounted for approx. $90 \%$ of the representation. Academics also rapidly mobilized to collectively assert themselves at the state level. For example, the General Council for Science and Higher Education (Rada Glówna Nauki i Szkolnictwa Wyższego) was created as a state-licensed body to represent the broader academic community and uphold its grip over policy design (OECD, 2006a, p. 77). The Polish Rectors' Conference (KRASP) also emerged as an advisory body to politically advocate the narrower interests of university rectors. Thus, while internal university operations were based on internal "stakeholder democracy," academics largely succeeded in gaining a monopoly over political interest intermediation, 
resulting in a "hyper-corporatist system" characterized by academic stakeholder dominance. ${ }^{1}$

However, faced with large-scale deindustrialization and unparalleled educational expansion (Kwiek, 2014), the Bologna Process provided Poland a window of opportunity to critically assess the viability of largely unregulated academic self-rule. A State Accreditation Commission (Państwowa Komisja Akredytacyjna) was established in 2001 to evaluate the quality of study programs based on relatively strict minimal standards. Again, here though, high-ranking academics turned the Commission into an additional bastion of academic power. Its members are appointed by the Minister of Education (from 2006, Minister of Higher Education and Science) but have consistently been high-ranking academics, upon nomination by (equally academic-dominated) academic senates and the General Council. Despite the introduction of some state-control and market-oriented instruments in the 2000s (Dobbins, 2014), the predominance of academic stakeholders in academic decision-making and state-licensed bodies remained extremely high by European comparison, whereby the power of the government and external stakeholders was very low (Shaw, 2018).

\subsection{The Czech Republic}

The roots of the Czech HE can be traced back to the 14th century with the establishment of Charles University in 1348, the oldest institution of higher learning in CEE. Despite increasing Czech influence after the mid-19th century, Charles University remained largely rooted in German institutions of Humboldtian inspiration. Core features were strong university autonomy, a weak central (university management) level as well as the so-called "federation of professorial chairs" (Sadlak, 1995, p. 46) with formidable blocking power. However, after World War II, Czech HE succumbed to communism: academic freedom and institutional autonomy were dismantled, while mainly political appointees took over university and faculty management. Research was almost entirely transferred to the Czechoslovak Academy of Sciences (established in 1953), and most teachers were cut off from international networks.

Amid the collapse of communism, policy-makers were extremely quick to reinstate Humboldtian university self-governance, bolstered by internal "democratic" structures, external buffer organizations, and strong student participation (Dobbins, 2011). Procedural and substantive autonomy was devolved to professorial chairs, which transformed the once hierarchical system into a highly fragmented one. The retreat of the state was reflected in the $1990 \mathrm{HE}$ Act that granted universities control over teaching and research programs as well as student numbers, admission criteria, leadership positions, and all internal structural decisions (ibid.). Rectors were also chosen by fellow high-ranking academics via academic senates and shared governance authority with them. Both academics and students were thus heavily represented in faculty and university senates. 
In fact, de Boer and Goedegebuure (2003, p. 219) spoke of the "abolition of government." Any policy change required the consensus of the Czech Rectors' Conference and Council of Higher Education Institutions (Rada vysokých škol), which consisted exclusively of academics, excluded external stakeholders and served to represent academic senates and faculties. The Council of Higher Education Institutions also comprised students, and subsequently, a student chamber of the Council was established, representing students' interest vis-à-vis not only academics but also the state. Thus, altogether, the post-1989 trajectory was swift and dramatic, as far-reaching university autonomy was reinstated practically overnight and facilitated by a widespread belief among politicians that $\mathrm{HE}$ institutions would be able to transform themselves from within (Šebková \& Hendrichová, 1995). Instead of initially seeking a more pragmatic relationship with the state, the academic community rapidly mobilized and consolidated to protect itself from state intrusions, both from within and outside.

Yet the Czech (and Polish) HE system was also confronted with an enormous quantitative challenge, namely its massification. Unlike in Poland, expansion primarily took place in the public system, resulting in drastically increasing student numbers (File \& Goedegebuure, 2003). The 1998 HE Act, therefore, aimed to increase the state's leverage to steer the system. However, in effect, all state institutions ${ }^{2}$ were fully transformed into public bodies with a legal ability to manage their own assets and properties, thus effectively separating them from the state. Within $\mathrm{HE}$ institutions, the powers of rectors were strengthened vis-à-vis individual faculties and other subunits. While faculties initially acted as independent legal entities, the 1998 Act cemented HE institutions as single legal entities. It also introduced a Board of Trustees, comprising of representatives from public life, municipal, and regional authorities and the state administration. However, its role was rather symbolic in comparison with the rector or the academic senate. The position of students was also substantially upgraded, as the Act specifically prescribed that they occupy a minimum of one-third and a maximum of one-half of senate seats on both faculty and university levels.

These foundations laid in the early 1990s remained remarkably stable in the 2000s - despite the Bologna Process and the reform ambitions of the new rightwing government coalition. Flanked by the 2006 OECD Thematic Review calling for sweeping changes in HE (OECD, 2006b), the so-called "White Book on Tertiary Education" (Matějů, 2008) provided strategic guidelines for drafting new HE legislation. It aimed to "open up" HE institutions, giving those who have a stake in the system - employers, regions, graduates, etc. - a greater say. It also anticipated more power for the state to steer the whole system. The document also touched upon a very complex issue of the system's structure. The existing system with the majority of institutions (the majority with respect to student numbers) having an ambition for research and high academic profile was not able to meet the increasingly diversified needs of students on the one hand, and the labor market on the other. 
However, partly due to political instability, the underlying policy and governance patterns only incrementally changed (Pabian, 2008), and the institutional privileging of academic interests served to uphold the Humboldt-oriented system. Above all, the lack of executive steering hindered measures that require transfaculty coordination. Thus, Czech HE remained characterized by a strong professoriate, collegial control, academic dominance of representative bodies and academic senates and a lack of entrepreneurial management structures.

\section{Explaining policy divergence}

We now, first, examine the striking policy shift toward centralization in Poland, again from a stakeholder perspective, before engaging with Czech policy developments. As shown above, the post-communist HE trajectory of both countries was essentially characterized by the large-scale mobilization of the academic community to fend off state control and consolidate academic "democracy." High-ranking academics gained representation monopolies at the state level through rectors' conferences and other academic interest bodies, while maintaining a strong grip over the state accreditation process. Within universities, academic senates remained bastions of academic self-governance, while the very fragmented internal structure of universities undermined the influence of university managers. Essentially, the post-communist pathways of both countries resulted in the convergence toward a model of academic "hyper-corporatism" at the state level and decentralized stakeholder self-governance at the university level.

\subsection{Poland: the "fake corporatist" pathway to the constitution for science}

The new Polish HE Act known as "Ustawa 2.0," which is embedded in a broader package of laws known as "Constitution for Science" (Konstitucja dla Nauki), constitutes a striking case of "divergence after convergence." We now focus on the policy style leading up to the reform and then discuss the policy output and shifts in stakeholder constellations. The 2010 international rankings continuously highlighted the weak competitiveness of Polish HE and Poland's poor performance in Horizon 2020 and ERC grants (Boyadjieva, 2017). While study programs became increasingly commercialized, research tended to proliferate low-quality publications. This led to a widespread perception that an overhaul of the system is necessary.

Therefore, the new (post-2015) PiS parliamentary majority (Prawo i Sprawiedliwość / Law and Justice) pushed for a reform package labeled: "complex change of approach to scientific research, teaching students and managing the university." In a seemingly stakeholder-friendly, democratic manner, PiS initiated an open competition for proposals (założenia do ustawy) for the legislative act. Of the fifteen original proposals, three most prominent ones emerged (Kwiek et al., 2016; Izdebski et al., 2017; Radwan, 2017), all of which recommended the concentration of resources in managerially operating rectors to the detriment of existing 
collegial bodies, while more systematically including external stakeholders in governance. Each paper viewed the excessive "democratization" and fragmentation of the university system as dysfunctional (e.g., Radwan, 2017, p. 37) and advocated a more managerial model.

Particularly striking was the open and inclusive nature of the process, at least on the surface. More than five thousand participants (including students, professors, managerial staff, etc.) participated in thematic conferences organized under the banner "National Congress of Science," arguably the largest consultation forum ever witnessed in Poland. However, numerous interviews conducted with stakeholders paint a different picture. For example, one stakeholder comments:

Consultations were conducted in a model way. There were many efforts to reach every university and region. However it did not affect the final reform, since almost everybody feels endangered by it.

(Interview 03 May 2019)

Another stakeholder claims: "This act was supposedly up for consultations for two years. We have voiced our claims, but nobody took them into consideration" (Interview 08 May 2019).

Other informants expressed more radical criticism, e.g.:

It was a purely political process. And propaganda of success.

(Interview 01 May 2019)

Consultations? Let's not joke. It was not a participatory process. There were crowds of people who were for the reform.

(Interview 06 May 2019)

Many informants also emphasized the gap between the initial ideas in the three policy papers and the Ministry's draft bill, e.g.:

There has never been a consultation process on this scale, but many voices were not heard and many things were changed at the parliamentary stage.

(Interview 03 June 2019)

Thus, while the draft bill was widely consulted in the prelegislative phase, the main details apparently were decided in ministerial corridors. Counter to the Ministry's claims of an open, democratic process, a largely façade exercise seems to have occurred. Specifically, the national-conservative government engaged in alliances with like-minded groups, in particular, university rectors, while essentially remaining deaf to arguments voiced by opposing stakeholders from more diffuse interest organizations (in particular, university researchers).

We label this policy-making mode "fake corporatism." Like in corporatist arrangements, decision-making power was to some extent transferred away from 
the parliament to socioeconomic interest groups. However, here it was not a matter of balancing interests and reaching consensus; rather, it was of legitimizing already predetermined policies. The authors of the three policy papers had to stick to the predefined modules during the drafting process. The ministry then organized "Byzantine-style" consultations, creating the feeling of inclusiveness among the various organized stakeholders. However, the most prominent and present stakeholders were those who already held representation monopolies, were state-funded and -licensed. The final act was then pushed through parliament without any open debate. As many interviewees claim, the consultations resembled the notion of "preaching to the convinced" (e.g., Interview 03 May 2019; Interview 09 May 2019). In other words, the consultations served to legitimize already predefined goals, which were then to be implemented by rectors. The other scattered, and often rivaling actors, were unable to effectively support their pluralistic demands (e.g., more funding for doctoral students, more system funding, more stakeholder democracy). ${ }^{3}$ Their participation in the large-scale consultations allowed them to voice their preferences but not much more. Essentially, their interests "sank" in the magma of the reform, and their relative power vis-à-vis rectors was substantially downgraded.

This policy-making mode also coincided well with the recent shift toward a "strong state," advocated by center-right governments in Poland. Drawing on the criticism of post-1989 liberal reforms and widespread systemic corruption, the PiS party, in particular, has endeavored to (re)build state-society and state-market relations from above. One of the main slogans since PiS regained a parliamentary majority in 2015 has been "Wstawanie z kolan" ("Rising from the knees"), thus a more proactive state seeking to regain true sovereignty and strength. This translated into various reforms leading toward empowering the state's position vis-à-vis many societal spheres and, hence, recentralization. Here, the state drew on an alliance with the rectors as "natural allies" to the detriment of long-standing traditions of internal academic self-governance.

\subsubsection{The new face of Polish HE}

The 2018 Act fundamentally transforms Polish HE and - despite the open civic engagement process on the façade - results in a situation in which the large majority of stakeholders are dissatisfied with the outcome (AKP, 2018b; Chrzczonowicz, 2018; Płuciennik, 2019). The Act defines the three organs of the university: University Council (Rada Uczelni), Rector, and Senate (Art. 17), among which the rector has the most authority. The University Council has the most strategic competences (Art. 18) and a supervisory function over the rector. Previously the most powerful university governing body, the Senate now focuses on teaching activities. University Council members are formally appointed by the Senate, but internal regulations allow the rector to exclusively propose the candidates, whereby a majority must be from outside the university community (Art. 18 Ustawa, 2018). The rector is elected by the University Council or 
college of electors and is responsible for managing the university, appointing (and dismissing) other managerial positions, as well as financial governance, representative functions, and many other areas (Art. 23 Ustawa, 2018). Rectors also decide on internal university regulations. The final version of the Act known as "Ustawa 2.0"4 grants the University Council hard competences in appointing the candidates for rectors, approving the financial plans and reports or monitoring university management and soft competences regarding the development of university strategies.

Upon enactment, "Ustawa 2.0" was again heavily criticized by many actors, including student unions as well as numerous labor unions (including NSZZ "Solidarność"), Forum Związków Zawodowych, 17 various scientific councils, and countless individuals (AKP, 2018b; Płuciennik, 2019), for its political infringement on university autonomy. The newly emerged protest group Akademicki Komitet Protestacyjny (AKP) organized an event entitled: "funeral of Polish science" and published a list of recommendations responding to the deficits of the reform, including the democratization of universities' democratic standards for rectors' elections and other managerial bodies, safeguarding autonomy by depriving the newly established "University Councils" of the right to appoint candidates for rectors, depoliticization of universities, guaranteeing transparency.

Apart from students who saw their equal access to HE (guaranteed by the constitution) endangered, academics also opposed the measures. "In the end of the reforms the rectors will be like gods" (Interview 02 May 2019), to the detriment of collegiality, self-governance, and faculty autonomy (Interview 03 May 2019). As one former dean noted: "With respect to autonomy, the faculties lost all their powers and are totally dependent on the rectors" (Interview 02 April 2019). Yet, not only the centrality of the rectors is perceived as problematic from the autonomy viewpoint, but the election process also is (Interview 10 May 2019). Specifically, the internal regulations allow the senate to control who will become the member of the Council (Interview 03 April 2019), whereas the Council determines the candidates for rectors. "Elections of rectors are like in Iran. We may choose among the candidates anointed by the Ayatollahs. This is not an election" (Interview 01 April 2019).

The critique of the new powers of rectors is not unjustified, considering that they oversee the whole university apparatus consisting of professional administration, lawyers, experts, scholars, etc. All this further concentrates their power resources and is funded by the state. How and why did the balance of power tip toward the rectors? We argue that interactions between two types of state power resources were critical: one politically organized by the Minister of Higher Education and Science, and the other corporatistically organized by the rectors. If we view the reform as an exchange between the two tax-funded groups in which one - the politicians have decision-making power and the other - the rectors - have the implementation power, then their synergy becomes crucially decisive from the point of view of reform success. 
Hence, the Minister strengthened the rectors, and vice versa, the rectors enabled the smooth implementation of the reform, thereby strengthening the minister. It made them the most natural allies since this collaborative power exchange was mutually beneficial.

Returning to our theory, it appears that the preexisting institutions of internal academic self-rule, a restrained state, and other groups representing university management in corporatist arenas, were subverted by a new state-rector alliance. For example, the General Council (Rada Glówna Nauki i Szkolnictwa Wyższego), consisting of heterogeneous representatives of academic teachers, students, labor unions, scientific institutions, etc. and formally a key player in the corporatist arrangements, was simply too diverse to speak with a common voice. Moreover, its statutory documents define it as a neutral agent, ${ }^{5}$ with the effect that it cannot engage in "power politics" and that its demands are more "horizontal" (i.e., more funding for HE and science). By contrast, the rectors, whose interests were heavily concentrated in the existing state-level corporatist structures and spoke with one common voice, essentially reaped most of the reform benefits, which, in turn, also increased the state's grip over policy. From the very beginning, their position was strengthened by the three policy papers recommending more executive authority for them. This equipped them with an external source of legitimation, supplementary to the already comparatively advantageous position vis-à-vis other actors. This encompasses not only the traditionally understood power resources, like finances or access to decision-makers, but also external justification (policy papers, experts, reform expectations) and a position in the already existing university hierarchies and access to state resources.

Last but not least, in the perception of many informants, centralization is not without purpose but falls in line with the thrust toward enhancing the state's leverage over various societal spheres, e.g., "Centralization and politicization, understood as 'full availability' of universities, is coded ideologically in this governance culture" (Interview 01 April 2019). The motivations revealed by the authors of the reform drew strong criticism: "Under the guise of the fight against nepotism and corrupt pathologies, a centralized system was created" (Interview 09 May 2019), which further concentrated authority within already privileged institutions and actors.

The upgrading of rectors in the governance structures is seen by most stakeholders as a vehicle for politicization. As one informant argues: "The rectors collectively mobilized. They received a lot of promises of power... They simply caught the hook" (Interview 04 May 2019). Others were much more explicit, e.g., "It is easier to politically steer or corrupt one person, the rector" (Interview 09 May 2019). Such judgmental statements were omnipresent in the interviewees' claims, which consistently reflected worries about decreasing academic autonomy (AKP, 2018a). For example: "Everybody is less independent. The professors are totally dependent on the rector. And the rectors on politicians (...) the whole reform is a political project" (Interview 01 May 2019). 


\subsection{The Czech Republic: keeping the status quo}

The foundations for academic stakeholder governance were laid early and proved to be much more change-resistant than in Poland. Šebková and Beneš (2002) still regarded a system of self-governance and high autonomy of HE institutions together with indirect state steering mainly by the distribution of financial means as two main characteristics of the Czech HE system around the turn of the millennium. This seems to be still true two decades later. Strong resistance to regulatory interference into academia has been always perceived as a step back to communist times. Along these lines, the three decades of post-revolutionary Czech HE have been marked by the persistent and collective mobilization of all internal academic groups (academics, students, and well as rectors) to preserve the system of academic freedom, autonomy, and self-governance. Czech HE can thus be seen as a "corporatist" system based on negotiation between the Ministry of Education and the formal representatives of HE institutions, comprising Council of Higher Education Institutions (since 1993 it also includes a student representation) and the Czech Rectors' Conference. Thus, on the surface, stakeholder governance in the Czech Republic and Poland is strikingly similar.

Why has the policy pathway taken in the early 1990s become so entrenched? The historical roots of the Czech HE legislation and how it was drafted and negotiated are crucial for understanding how and why internal interest groups have successfully resisted reform attempts, including the last major amendment in 2016. Since 1990, HE policy has been based on consensus and must be implemented very carefully to cater to the sensitivities of academics. In line with legislation, all major measures are discussed with representatives of $\mathrm{HE}$ institutions. The 1990 Act incorporated the Council of Higher Education Institutions into policy-making, enabling it to be consulted on any "fundamental proposals and measures concerning higher education." These constellations were further consolidated in 1998 by also including the already existing Czech Rectors' Conference into all HE matters "having a significant impact on higher education institutions." This provision has been interpreted basically in a way that without consensus from the academic community no changes can be introduced.

The HE Act has always been attributed a high symbolic value within academia itself, not only because of its origin (partly associated with the "Velvet Revolution" of November 1989 and the student movement in bringing down communism) but also because of the legal protection it offered to academic staff and student interests (Interview 01 January 2020). Any attempt to alter the legislation thus faced profound opposition primarily on these grounds. Thus, the 1990s saw the emergence of a weak state and strong academic community in Czech HE, which has had long ramifications for the system. During all reform attempts, the Ministry of Education was responsible for drafting new legislation, whereby the process was generally dominated by internal HE stakeholders such as rectors, the HE Council, and students.

In the early reform phase, the relationship between rectors and the state developed in a rather antagonistic manner. The leading Czech HE institutions 
Charles University, and mainly its Faculty of Law, have been heavily involved in policy-making and essentially steer policy-making from both within and outside the parliament. For example, in the mid-1990s, the rector of Charles University, Karel Malý, sent a personal letter to all members of parliament who graduated at his university, asking them to block the proposed HE act because it deprived universities of their fundamental rights and freedoms (Interview 13 December 2019). This is no exceptional case, as Czech rectors have traditionally relied on members of parliament who are former graduates of their own institutions (mainly Charles University) to mobilize support against more managerial reforms. During this specific case in the 1990s, the Faculty of Law of Charles University even submitted its own reform proposal, which was chosen over the initial ministerial proposal as the main fundament for the new HE Act in 1998.

Even after the implementation of the Act in 1999, tensions between the Ministry of Education and HE institutions remained high, as demonstrated by the proclamation of the Czech Rectors' Conference: "they ask for the establishment of the new ministry for higher education and science as the existing Ministry of Education, Youth and Sports does not defend the interests of higher education institutions." Leading academics pushed to establish a new ministry for science and HE from time to time, aiming to consolidate their dominance of the sector. However, HE and science have remained with the Ministry of Education, Youth and Sport with a dedicated deputy minister, who, essentially, always had an academic background. Since the Ministry is also responsible for primary, secondary schools, youth, and sport, HE has to some extent remained on the backburner of the ministry's agenda, again enabling academics to self-govern the system. Thus, during the period between 1994 and 1998, the main interest groups profiled and the playing field was structured. The Ministry of Education representing the state succumbed to its weak position with respect to steering the system. Public HE institutions increased their power mainly by transforming from the state into public institutions, an idea which also goes back to members of the Faculty of Law of Charles University, who thereby drafted the law and transferred the model of municipalities as public-law corporations to HE institutions (Interview 13 December 2019; Interview 20 January 2020).

In the 2000s, the Czech Rectors' Conference and the Council of Higher Education Institutions reaffirmed their positions as the two main representations affecting the HE agenda. Students emancipated themselves within the Council of Higher Education Institutions and became an important player in the field they not only brought their agenda to the Council, they also negotiated with the Ministry of Education and other stakeholders separately (Interview 20 January 2020; Interview 17 December 2019). Despite some disagreement on some issues, rectors, academics, and students have repeatedly acted as a consolidated unit to protect university autonomy. No other external players such as employers, chambers of business, not-for-profit organizations, or other representatives of public or any other interest groups have been intensively involved in the process. 


\subsubsection{A long-lasting reform attempt}

While the recent about-face in Polish HE occurred rather dramatically, the most recent amendment to the $\mathrm{HE}$ Act (2016) is the result of a long-term reform process stimulated by the already-mentioned Thematic Review of Tertiary Education (2006) undertaken by OECD experts and seized on by the right-wing government then. The OECD suggested changes regarding the system structure, its diversification and the institutional landscape, institutional governance, resourcing, access and equity, connections to the labor market, and many others. Like in Poland, Czech HE stakeholders were also heavily involved. While both the Prime Minister and the Minister of Education at that time were not associated with academia, the Deputy Minister responsible for Higher Education and Science, Petr Matějů, was a professor himself, albeit a big critic of the existing system and proponent of private education and tuition fees (Interview 13 December 2019).

A team consisting of both ministerial as well as external members published the "White Book on Tertiary Education" (Matějů, 2008) as the main strategic guideline for drafting the new HE legislation. The document offered some alternatives to the existing system, arguing for the introduction of governance changes and making HE more open to those who have a "stake" in the institutions and the system as a whole - employers, regions, graduates, etc. The White Book itself received very critical reactions, mainly from old traditional universities and also on personal grounds. Unlike in the recent Polish reform, representatives of academic self-governance - traditional universities, rectors, academics - were not members of the drafting team.

However, the original intentions were never met. Due to governmental instability and political turbulence, the main governmental players were unable to defend the reform project. Between 2006 and 2009, as many as five ministers and four deputy ministers for $\mathrm{HE}$ and science changed. Well organized representatives of $\mathrm{HE}$ institutions did not have a stable and reliable partner for government negotiations, resulting essentially in the institutional inertia of the system established in the 1990s.

After the vote of no confidence in the Parliament and subsequent resignation of the coalition government in spring 2009, HE reform was halted by the then minister (Interview 12 December 2019), and the caretaker government took power during 2009-2010. After early elections in May 2010, a center-right government took power with Petr Nečas replacing Mirek Topolánek as Prime Minister. Its policy statement included the introduction of differed tuition fees and a supplementary loan scheme. The reform draft, to some extent, constituted an attack on internal university democracy by calling for a strengthened role of the Board of Trustees, limiting student representation in the senates to onethird, and changing the system of docents and professors from academic titles into working positions. The draft, which would have diminished the influence of major internal groups - rectors, academics, and students - met with intensive 
criticism from students, resulting in mass demonstrations under the motto "the week of unrest" in 2012. Charles University was also very active in opposing the reform. ${ }^{7}$ The minister resigned, and his successor, a political science professor and former rector of Masaryk University, first softened their initial enthusiasm for the reform and eventually abandoned the entirely new legislation, while instead pushing for changes within the existing legislation (Interview 20 January 2020; Interview 21 January 2020).

After intensive discussion with HE representations, an amendment to the HE Act was ultimately passed in 2016. Even ten years since the White Book, it essentially did not include any changes suggested either by the OECD experts or previous reform-minded governments. It did not enable the greater participation of external stakeholders in HE governance nor did it increase in any way the leverage of the state or its surrogates (as was the case with the Polish Rectors' Conference) over HE. Specifically, the previous Accreditation Commission was transferred into the National Accreditation Office, making it more independent from the state. The management and chairs of various working groups include almost exclusively members of academia with only minor involvement of external stakeholders. The new amendment also introduced a new possibility within the accreditation process: upon meeting certain requirements, a HE institution can be awarded an "institutional accreditation", thus the autonomy to create and abolish study programs internally. Accreditation and quality assessment were partly moved from an external actor (Accreditation Commission) into internal processes. Hence, the ultimate outcome of the 10-year reform endeavor, which originally aimed to strengthen the state's ability to steer the system, is essentially a further increase in the autonomy and self-governing capacities of HE institutions (Interview 21 January 2020).

What accounts for the striking level of institutional inertia in Czech HE? First, the intermingling of politics and Czech academics - mainly those in managerial positions - was decisive. Leading academics have been active in politics on all levels - municipal, regional, national, and EU. Due to the high prestige of university professors and the academic profession in society in general, political parties have actively sought and engaged them for elections. The Parliament has consistently included around five high-ranking academics, mostly former or even active deans or rectors of public universities. Former rectors of Charles University as well as Masaryk University are now members of the Senate. The former rector of Masaryk University is now a leader of the right-wing opposition party. In fact, many of the deputy ministers responsible for HE and science have been former rectors or deans. Usually, the main and only task of the ministry with respect to HE was to ensure as many resources as possible for the system that has been supposedly underfinanced. Traditionally, the Ministry, through the deputy minister responsible for $\mathrm{HE}$ and science (with some short-lasting exceptions), has represented the interests of the HE community rather than the state or the public. These dual affiliations and resulting inter-parliamentary and outer-parliamentary power resources put them in a privileged position, thus diminishing the prospects of rector "power grab" as in the Polish case. 
This balancing act of many Czech rectors and other high-ranking academics between the political sphere and their universities, combined with a supreme degree of inter-university decentralization, has had the effect that Czech rectors have not succeeded in centralizing their institutions. Traditionally, they have been treated more as representatives of their universities rather than general managers with the deans as their deputies (Interview 27 November 2019; Interview 28 November 2019; Interview 4 December 2019). In 1998, universities indeed became legal entities. However, in reality, very little has changed. The faculties are still the main actors within the university. In fact, rectors have been usually those with higher political ambitions. Their position was rather weak within their institutions, but strong in the HE system - representing the universities visà-vis the Ministry. It could be described as a division of power within the system. "As long as you leave us faculties alone within our domain, you rectors can go ahead and play your political games with the ministry and the state" (Interview 28 November 2019).

Finally, Czech students have been seen as a symbol of the revolution - they went to the streets in 1989 and ultimately helped bring down communism. In Czech society, there is a strong nostalgic and sentimental attachment with student interests, which are frequently automatically equated with university interests. Whenever the state moved to change the balance of power to its benefit by taking away a bit of power from the universities, students, and academics quickly and effectively collectively mobilized to earn the sympathy of the public. This often translated into a public backlash according to the motto "Do not endanger those who gave us the freedom!" Thus, altogether, the symbolic position of universities and students in the revolutionary phase also explains their high social status and strong lobbying power.

\section{Conclusions}

The Czech Republic and Poland embarked on a remarkably similar reform pathway after 1989 , by essentially turning back control over HE to the academic community. University autonomy, academic freedom, and the democratization of university governance were crucial early steps toward democracy. This resulted in the quick and effective restoration of academic self-governance and the creation of numerous institutions and organizations to defend the independence of the academic profession (Dobbins, 2011; Kwiek, 2014).

Why was the Polish government able to vertically impose a reform largely undesired by the academic community and amid resistance from previously potent stakeholders? And why has the Czech government failed, time and time, again to reform and "managerialize" university governance? We argued that the reasons for recent policy divergence lie in the differential mobilization capacities of academic stakeholders and the state's means for intervention.

Regarding the power distribution within the academia, universities have been historically fragmented with power vested in faculties or even departments. 
In the Czech case, this posed a substantial obstacle to institutional centralization and strengthening university management and rectors. It seems that a tacit agreement has been in place between rectors and deans about the distribution of power in institutional and national policy-making. Another striking phenomenon is the active involvement of academic management in general politics, allowing for intensive inner and extra-parliamentary mobilization for academic interests. Former or even acting rectors and deans have been represented across different political parties but consistently have been able to find a united position to defend their interests.

Thus, the Czech post-communist structures of academic democracy have consolidated over almost three decades, and strong internal stakeholdership has evolved. Indeed, the abovementioned internal stakeholders stated that their influence within the system has either remained the same or increased (Survey Response 15 April 2019). By contrast, external stakeholders, represented by the state/ministry and other players including business, employers, or regional authorities, have never been able to form an adequate counterbalance vis-à-vis internal academic stakeholders.

In Poland, by contrast, pre- and post-communist structures of academic democracy (i.e., university as a community of scholars) were converted into semi-autocratic state-rector alliance. Following Olson's "optimal group size" claim, the rectors, organized in KRASP and various other institutions, enjoyed a strong organizational advantage over other diffused academic interests. This led to a coalescence of interests between the national-conservative government aiming to reassert control over the sector and rectors, who stood to benefit from the centralization of powers within universities. Subsequently, the top of the managerial university structures - i.e., rectors - became the powerful agents of governmental policy change. This resulted in the relative downgrading of the interests of other stakeholders (faculties, institutes, departments, and even individual academics) as they have become more dependent on the rector and his/her interests. On the one hand, more diffuse and fragmented groups were unable to collectively mobilize effectively due to the pluralist setting of the various stakeholders. On the other hand, it was in the interest of the authorities pursuing the reform to focus on one interest group, namely the rectors, who were critical for the implementation of the reform. Thus, the reform not only reorganized university governance by endowing rectors with unprecedented power at the cost of other previously influential, but fragmented, collegial bodies but also places more power in the hands of politicians.

The Polish HE reform indeed can be seen in the larger context of the post2015 political changes reflecting illiberal tendencies, democratic backsliding, and centralization. Centralization (on a systemic and university level), politicization, and disruptions to academic autonomy bring about winners and losers. The return of the strong state is an influential precondition and incentive for translating the public financial dependency into dependency on public authority which, in such a politicized system as the Polish one, automatically means 
political dependency. After the judiciary and other spheres of public life, the Polish academic sector has thus become an additional arena in which purportedly well-intended reforms brought about politicization and centralization. Although it has been a long time since Poland departed from its ideologically driven, overregulated, and inefficient communist-type HE system, some symptoms of the past seem to be returning. It remains to be seen whether the Czech system will soon move in the same direction.

\section{Notes}

1 For a historical account of student activism in Poland, see Junes (2011).

2 With the exception of the University of Defence and the Police Academy.

3 Students demanded more money for scholarships, etc. and actually received it, albeit at more limited numbers. So there is similar amount of money for them in the system, but it is simply allocated among fewer individuals.

4 "Ustawa 2.0" - the renewal of Ustawa "Prawo o szkolnictwie wyższym i nauce" was voted on 03 July 2018; 233 deputies were for, 195 against, 1 abstained. This vote shows there was no general consensus.

5 http://www.rgnisw.nauka.gov.pl/statut/

6 Quoted by the Czech Press Agency on 19 November 1999.

7 The text "Kritický privvodce 'reformou' vysokých škol" is available here: https://iforum. cuni.cz/IFORUM-12056.html.

\section{References}

AKP. (2018a). Tezy Poznańskie. Poznań: https://www.facebook.com/akademickikomitet protestacyjnypoznan/photos/pcb.1717252221693634/1717251971693659/?type $=3 \&$ theater (Accessed 29 May 2019).

AKP. (2018b). Akademicki Komitet Protestacyjny; Oświadczenie AKP po III czytaniu Ustawy 2.0, https://www.facebook.com/notes/akademicki-komitet-protestacyjny/ oświadczenie-akp-po-iii-czytaniu-ustawy-20/801644110042533/ (Accessed 29 May 2019).

Bennett, A. \& George, A. (2005). Case studies and theory development in the social sciences. Cambridge, MA: MIT Press.

de Boer, H. \& Goedegebuure, L. (2003). New rules of the game? Reflections on governance, management, and systems change. In J. File \& L. Goedegebuure (Eds.), Real-time systems. Enschede: Logo CHEPS, pp. 207-234.

Boyadjieva, P. (2017). Invisible higher education: Higher education institutions from Central and Eastern Europe in global rankings. European Educational Research Journal 16(5), 529-546.

Chrzczonowicz, M. (2018). Protest przeciwko ustawie Gowina. Aktywistka wbiegła na scene I przerwała wystapienie ministra, https://oko.press/protest-przeciwko-ustawie-gowinaaktywistka-wbiegla-na-scene-i-przerwala-wystapienie-ministra-film/ (Accessed 28 May 2019).

Clark, B. (1983). The higher education system. Berkeley: University of California Press.

Dobbins, M. (2011). Explaining different pathways in higher education policy in Romania and the Czech Republic, Comparative Education 47(2), 223-245. doi: 10.1080/03050068.2011.555116 
Dobbins, M. (2014). Exploring the governance of Polish public higher education: Balancing restored historical legacies with Europeanization and market pressures, European Journal of Higher Education 5(1), 13-33. doi: 10.1080/21568235.2014.969289

Duczmal, W. (2006). The rise of private higher education in Poland: Policies, markets and strategies. Dissertation. Universiteit Twente: CHEPS.

File, J. \& Goedegebuure, L. (2003). On Real-time Systems, Change and Challenge Comparative reflections. In J. File \&, L. Goedegebuure (Eds.), Real-time systems. Enschede: Logo CHEPS, pp. 235-246.

Gornitzka, Å. \& Maassen, P. (2000). Hybrid steering approaches with respect to European higher education, Higher Education Policy 13(3), 267-285.

Greskovits, B. (2015). The hollowing and backsliding of democracy in East Central Europe, Global Policy 6(51), 28-37.

Ilnicki, G. (2019). cit in: Jankowska E. (2019), Mobbing na uczelniach wyższych. „Byłam szykanowana, obrażana w trakcie zebrań zespołu, rozpuszczano plotki na mój temat". Gazeta.pl.weekend, http://weekend.gazeta.pl/weekend/1,152121,24821405, mobbing-na-uczelniach-wyzszych-bylam-szykanowana-obrazana.html (Accessed 30 May 2019).

Izdebski, H. (2019). Ustawa 2.0 - merytorycznie w pozadku, legislacyjnie - poniżej przeciętnej, Prawo.pl, https://www.prawo.pl/student/prawo-o-szkolnictwie-wyzszym-ocenaprof-huberta-izdebskiego, 391284.html (Accessed 03 May 2019).

Izdebski, H., Świergiel, A., Chmielnicki, P., Ruszkowski, P., Misiąg, W., Kiebała, A., \& Zieliński, J. (2017). Propozycje założeń do ustawy regulujacej system szkolnictwa wyższego, Wydawnictwo SWPS, Warszawa.

Junes, T. (2011). Resisting communism in Poland: Traditions of student self-government, Warsaw East European Review 1, 2011.

Jungblut, J. \& Vukasovic, M. (2013). And now for something completely different? Re-examining hybrid steering approaches in higher education, Higher Education Policy 26(4), 447-461. doi: 10.1057/hep.2013.28

Klemenčič, M. (2012). Student representation in Western Europe: Introduction to the special issue, European Journal of Higher Education 2(1), 2-19. doi: $10.1080 / 21568235.2012 .695058$

Klemenčič, M. (2014). Student power in a global perspective and contemporary trends in student organizing, Studies in Higher Education 39(3), 396-411. doi: 10.1080/03075079.2014.896177

Kwiek, M. (2014). Structural changes in the Polish higher educational system (19902010): A synthetic view, European Journal of Higher Education 4(3), 266-280. doi: 10.1080/21568235.2014.905965

Kwiek, M., Antonowicz, D., Brdulak, J, Hulicka, M., Jędrzejewski, T., Kowalski, R., Kulczycki, E., Szadkowski, K., Szot, A., \& Wolszczak-Derlacz, J. (2016). Projekt założeń do ustawy Prawo o szkolnictwie wyższym. Poznań: Uniwersytet im. Adama Mickiewicza.

Matějū, P. (2008). Bílá kniha terciárního vzdělávání. Praha: MŠMT.

OECD. (2006a). OECD thematic review of tertiary education: Country background report for Poland. Warsaw: OECD.

OECD. (2006b). OECD country note Czech Republic. Paris: OECD.

Olson, M. (1965). The logic of collective action. Cambridge, MA: Harvard University Press.

Pabian, P. (2008). Europeanisation of higher education governance in the post-communist context: The case of the Czech Republic. In, G. Neave, P. Maassen, \& C. Musselin (Eds.), Bologna, universities and bureaucrats. Dordrecht: Springer, pp. 257-278. 
Płuciennik, J. (2019). Diabelny bałagan z reformą Gowina w Polsce, Liberte, https:// liberte.pl/diabelny-balagan-z-reforma-gowina-w-polsce/ (Accessed 28 May 2019).

Radwan, A. (2017). Plus ratio quam vis consuetudinis. Reforma nauki i akademii w Ustawie 2.0, Wyd. 2, Kraków 2017.

Sadlak, J. (1995). In search of the post-communist university. In K. Hüfner (Ed.), Higher education reform processes in Central and Eastern Europe. Frankfurt: Peter Lang, pp. 43-62.

Sata, R., \& Karolewski, I. P. (2020). Caesarean politics in Hungary and Poland, East European Politics 36(2), 206-225. doi: 10.1080/21599165.2019.1703694

Schmitter, P. C. \& Streeck, W. (1999). The organization of business interest. Studying associative action of business in advanced industrial societies. Discussion Paper 99/1. Cologne: Max Planck Institute for the Study of Societies.

Šebková, H., \& Beneš, J. (2002). Changes and innovation of the governance in higher education system in the Czech Republic. Paper presented at the IMHE General Conference, Paris.

Šebková, H., \& Hendrichová, J. (1995). Decision-making in the Czech higher education after November, 1989. In K. Hüfner (Ed.), Higher education reform processes in Central and Eastern Europe. Frankfurt am Main: Peter Lang, pp. 109-117.

Shaw, M. (2018). Public accountability versus academic independence: Tensions of public higher education governance in Poland, Studies in Higher Education 44(12), 1-14. doi: 10.1080/03075079.2018.1483910

Smoleński, J. (2018). Gowin chce zmniejszyć samorządność uczelni, stawia w zamian na quasi-biznesowe rady, OKO.press, https://oko.press/gowin-chce-zmniejszycsamorzadnosc-uczelni-stawia-zamian-quasi-biznesowe-rady/ (Accessed 30 May 2019).

Tandberg, D. (2010). Politics, interest groups and state funding of public higher education, Research in Higher Education 51(5), 416-450. doi: 10.1007/s11162-010-9164-5

Ustawa "Prawo o szkolnictwie wyższym i nauce". (2018). Dziennik Ustaw Rzeczypospolitej Polskiej z 30. Sierpnia 2018 roku

Vachudova, M. (2011). Tempered by the EU? Political parties and party systems before and after accession, Journal of European Public Policy 15(6), 861-879. doi: 10.1080/13501760802196614

van Beek, U. (1995). The case of Poland. In: R. Mayntz, U. Schimank, \& P. Weingart (Eds.), Transformation mittel- und osteuropäischer Wissenschafssysteme. Opladen: Leske \& Budrich, pp. 256-301.

Vukasovic, M. (2018). Stakeholder organizations and multi-level governance of higher education. 23, 2018. In B. Cantwell, H. Coates, \& R. King (Eds.), Handbook on the politics of higher education. Cheltenham: Edward Elgar Publishing, pp. 413-430. doi: $10.4337 / 9781786435026$

World Bank. (2004) Tertiary education in Poland. Edition I. Warsaw.

\section{Interviews Czech Republic:}

Interview 15 April 2019 - Member of Council of Higher Education Institutions

Interview 27 November 2019 - rector of a public university and member of Czech Rectors' Conference

Interview 28 November 2019 - faculty dean of public university

Interview 4 November 2019 - former dean and rector of public university

Interview 12 December 2019 - former rector of public university and deputy minister responsible for higher education and science

Interview 13 December 2019 - former adviser to minister of education 
Interview 17 December 2019 - former student member of the Council of Higher Education Institutions

Interview 20 January 2020 - former student member of university senate, former director of department at the Ministry of Education and a former deputy minister of education.

Interview 21 January 2020 - former member of the Council of Higher Education Institutions

\section{Interviews Poland:}

Interview 01 April 2019 - director of institute, responsible for reform implementation at Opole University

Interview 02 April 2019 - member of the committee implementing the reform at UMCS Lublin

Interview 03 April 2019 - member of Obywatele Nauki ("Citizens for Science"): director of largest institute at the University of Warsaw

Interview 01 May 2019 - former rector of the University of Warsaw

Interview 02 May 2019 - director of one of the largest institutes, responsible for reform implementation t the institute's level, university professor, University of Warsaw

Interview 03 May 2019 - vice-director of one of the institutes, responsible for reform implementation the reform at University of Opole

Interview 04 May 2019 - dean of large faculty at UMCS Lublin

Interview 06 May 2019 - vice-rector of University of Warsaw

Interview 08 May 2019 - rector of private university in Warsaw

Interview 09 May 2019 - former vice-rector of Warsaw University

Interview 10 May 2019 - rector of private university in Warsaw

Interview 03 June 2019 -member of the executive committee of Parlament Studentów RP 